time lead to expeditious finding of fact and yet minimize the dangers to the individuals concerned.

The first such alternative is the traditional one: the use of immunity statutes. ${ }^{88}$ These statutes afford the witness protection from prosecution based on the testimony involved. Since there can be no guilt established on the basis of the testimony under an immunity statute, the witness cannot incriminate himself and the privilege ceases. This would of course obviate the necessity for the instant statutes since the employee called to testify could not withhold information without being guilty of contempt. If in so testifying the witness revealed guilt of corruption, etc. he could be dismissed. Such a dismissal would be on the basis of an absolute admission of guilt, rather than on mere inferences as is the case with the instant statutes.

The second alternative is to afford public officials special treatment in the area of self-incrimination by way of constitutional amendment rather than legislative enactment. This method is not a novel one as evidenced by the provisions in the constitutions of several states. ${ }^{89}$ Resort to the inclusion of specific limitations of the use of the privilege in the constitution has the distinct advantage, inherent in the amending process, of curtailing legislative encroachment upon historic liberties and rights ". . . because of some accident of immediate overwhelming interest which appeals to the feelings and distorts the judgment." ${ }^{90}$

\title{
THE ADMINISTRATION OF DIVORCE: A PHILADELPHIA STUDY +
}

"In the whole administration of justice there is nothing that even remotely can compare in terms of rottenness with divorce proceedings." 1 This sweeping criticism, as startling as it may seem in light of the importance to the state of the legal dissolution of families, is in fact typical of indictments being directed at the entire divorce procedure by lawyers, judges, and sociologists. Some critics attack particularly the lack of uniformity among divorce provisions of the various states, ${ }^{2}$ while others are

88. See note 10 supra.

89. E.g., N.Y. Const. Art. I, $\$ 6$ (testimony before grand jury); PA. Const. Art. 3 , $\$ 32$ (in proceedings against persons charged with bribery or corrupt solicitation. Immunity is granted).

90. Holmes, J. in Northern Securities Co. v. United States, 193 U.S. 197, 400 (1904), cited in Matter of Doyle, 257 N.Y. 244, 268, 177 N.E. 489, 498 (1931).

$\dagger$ The research for this Note was financed by a grant from the Thomas Skelton Harrison Foundation, an agency created by the will of Thomas Skelton Harrison to promote good government in Philadelphia.

1. Smith, Dishonest Divorce, 180 ATL. Monthly 43 (Dec. 1947). "Practically all divorces today are uncontested. . These uncontested cases are, in fact, agreed-to cases. Everybody knows it. Everybody must pretend not to know it." Ibid.

2. "The only complete solution of the whole problem of marriage and divorce in the United States is a constitutional amendment authorizing a national marriage and divorce law." Franklin, Dilemma of Migratory Divorces: A Partial Solution Through Federal Legislation, 1 OKLA. L. REv. 151, 170 (1948). 
concerned that the gap between legal doctrine and actual practice encourages deception and lack of respect for the law. ${ }^{3}$ It has been recognized that there is a need for empirical investigation in the area to consider the forces which actually control the legal termination of the marriage relationship. Because relevant statutes and appellate court decisions do not tell the whole story of divorce, an investigation of divorce administration in one city was undertaken. ${ }^{5}$ This Note is the result: a study of just how people get divorced in Philadelphia. The sociological problems concerning the causes of divorce are not dealt with. The substantive law is examined only insofar as it provides a basis for an appraisal of its administration. Although the study was confined to Philadelphia, its implications may well apply to other parts of Pennsylvania and other states where there is a similarity of procedures and of other operative factors.

\section{The Importance of Divorce Law Administration}

It is often assumed that variations in the divorce rates among jurisdictions are due to (a) lack of uniformity in the statutory grounds for divorce and (b) differences in the residence requirements of the various states. Actually, however, closer analysis reveals that divorce rate differences are not influenced solely by the laws themselves, but also to a great extent by the administration of those laws.

(a) The Grounds.-In Pennsylvania the grounds for divorce ${ }^{6}$ provided in the statute are: impotency, marriage with knowledge of prior subsisting marriage, adultery, desertion, cruel and barbarous treatment, indignities, fraud or coercion, conviction of crime, incestuous marriage and marriage on false rumor of spouse's death. ${ }^{7}$ Desertion and the various kinds of cruelty are by far the most frequently pressed grounds for divorce

3. "Social research has further complicated any interpretation we may make of the relationship between divorce laws and their impact upon the structure of the family, for it has been conclusively shown that the legal provisions for divorce are not an index to the real reasons why marriages break up. Divorce provisions are merely the allowable reasons which have become the legal fictions whereby men and women secure divorce." Elliott, Divorce Legislation and Family Instability, 272 ANNALS 134, 145 (1950).

4. ". . There has been a great deal of writing about divorce and relatively little empirical investigation." KePHART, A STUdY of Divorce: PhrLadelphia CounTy, 1937-1950 (unpublished thesis in University of Pennsylvania Library, 1951). See also Bradway, A Proposed Program for Research in American Fadmity LAw (1949).

5. Much of the data in this note was obtained by means of interviews with practicing attorneys, judges, court employees and others concerned with the administration of divorce in Philadelphia. In addition, court dockets and masters' reports were examined. Masters' hearings, which are usually held in private, were attended with the permission of two of the seven common pleas courts in Philadelphia. The verbatim testimony quoted throughout the Note was taken from the official court stenographers' transcripts.

6. Divorce in Pennsylvania is of two types: a mensa et thoro (from bed and board), which is a judicial separation available only to the wife, and divorce $a$ vinculo matrimonii, which is a complete dissolution of the marriage. Actions for divorce a mensa et thoro are relatively rare in Philadelphia, occurring at the rate of only one or two a year. As hereinafter used divorce shall mean a divorce a vinculo matrimonii.

7. Pa. Stat. AnN. tit. 23, §10 (Purdon Supp. 1952). 
both nationally ${ }^{8}$ and in Philadelphia $^{9}$ and they account for the vast majority of divorces actually granted. Even though the statutes of the various states differ in respect to many of the grounds stated, practically all contain desertion and cruelty. ${ }^{10}$ Therefore, despite the vigorous criticism of the chaotic state of the divorce laws and the ubiquitous call for uniformity, ${ }^{11}$ there appears to be more uniformity in practice than a mere comparison of statutes would indicate.

(b) Residence Requirements.-Undoubtedly variances in the divorce rates among states are due in some part to the residence requirements. The high rate in some states is unquestionably due to many migratory divorces and these are most common where the required duration of residence in the state prior to the filing of the divorce is relatively short. However, the fact that the residence factor should not be given undue weight may be illustrated by a single example: although both Nevada and Idaho require six weeks residence prior to filing divorce papers, ${ }^{12}$ and the grounds in these two states are not substantially different, ${ }^{13}$ many more divorces are granted in Nevada than in Idaho. ${ }^{14}$

Experience both in the United States and abroad has shown that a rigid divorce law will not necessarily result in a lower divorce rate unless it can be, and actually is, strictly enforced. ${ }^{15}$ For example, the statutory

8. 17 Bureau of the Census, Vital Statistics-Spectal Reports No. 25, Drvorce STATISTrCs 464 (1943).

9. In a random sample of 1434 divorces granted in the period between 1937 and 1950 , divorces granted on the grounds of desertion accounted for $46.9 \%$ of the cases, $29.7 \%$ of the divorces were granted for indignities and $16.8 \%$ for both indignities and cruelty. Thus only $7.1 \%$ of the cases were brought on all the other grounds combined. The yearly figures show a downward trend of divorces granted on desertion grounds and an increase in the number of divorces granted on the indignities ground. It is interesting to note that only $1 \%$ of the divorces are granted on the ground of cruel and barbarous treatment alone. KEPHART, op. cit. supra note 4.

10. Examination of the various state statutes reveals that 46 states grant divorce for desertion (or abandonment) and 43 for cruelty or indignities. In addition, in most states where desertion and cruelty are not recognized as grounds for absolute divorce, they constitute grounds for divorce from bed and board. For cruelty as a ground for divorce from bed and board, see MD. ANN. CODE GEN. LAws art. 16, \$34 (1951); Mrch. Stat. AnN. tit. 18, \$25.87 (1937); VA. Code tit. 20, \$95 (1950). For cruelty and desertion as grounds for divorce from bed and board, see N.C. GEN. STAT. c. 50, $\$ 7$ (1950). New York grants divorce for neither desertion nor cruelty. N.Y. Domestic Relations Law \$7.

11. See note 2 supra. 1934).

12. Idaho Code ANn. $\$ 32-701$ (1948); Nev. Comp. Laws ANn. $\$ 9460$ (Supp.

13. The grounds in Idaho are: adultery, extreme cruelty, wilful desertion, wilful neglect, habitual intemperance, conviction of felony, and insanity. IDAHO CODE ANN. $\$ 32-603$ (1948).

Divorce is granted in Nevada for impotency, adultery, desertion, conviction of crime, habitual drunkenness, extreme cruelty, neglect and insanity. NEV. CoMp. LAws ANN. \$9460 (Supp. 1934).

14. 31 Bureau of the Census, Vttal Statistics-Special Report No. 16, DrNoRCE Statistics 225 (1949).

15. For example, a divorce is granted in Sweden at the mere request of either party after a legal separation of one year. The separation is granted if both the husband and the wife declare that "because of a deep and lasting disagreement they cannot continue to live together." Sergerstedt and Weintraub, Marriage and Divorce in Sweden, 272 ANNALs 185, 189 (1950). This is actually a form of divorce by 
grounds for divorce in Nevada, ${ }^{16}$ which has become known as an "easy" divorce state, are not substantially different from those of Pennsylvania and other states which have much lower divorce rates. ${ }^{17}$ Therefore, in the absence of any sociological evidence which might indicate that the populations of certain states are to any marked degree less maritally stable than the others, and assuming that migratory divorces are most common where they are easiest to obtain, the great differences in divorce rates among the states must be attributed to the manner in which the statutes are administered, rather than to substantive statutory differences.

Recognizing the importance of the administration of the law in its effect on divorce rates, the administration of the divorce law of Pennsylvania in its largest city remains to be examined.

\section{Administration of Divorce in Phizadelphia}

Bringing the Divorce Action.-In Pennsylvania an action for divorce may be brought only in a county in which either the plaintiff or the defendant resides. ${ }^{18}$ Service may be made on the defendant by the sheriff in any county in the Commonwealth, by a constable of the county in which the action is pending, or, if service is made outside the Commonwealth, by registered mail with a signed receipt. ${ }^{19}$ Where personal service on the defendant cannot be had because he or she cannot be found, the master calls a meeting at which the plaintiff is questioned as to the whereabouts of the defendant. ${ }^{20}$ Information is sought concerning any lodges, clubs, churches or other organizations to which the defendant belonged and which might furnish a lead to the location of the defendant. This meeting is usually perfunctory and generally results in the master's determination that service can be made only by publication. The Pennsylvania rules require that the complaint in divorce set forth the names of the parties, the date and place of the marriage, and the citizenship, the last known residence and present whereabouts of the defendant to the best of the plaintiff's knowledge. The residence and the length of time that the plaintiff has resided in Pennsylvania must also be included. The rules further

consent-a result which our American statutes would never allow. In addition, immediate divorce for misbehavior of a party is permissible. Yet the divorce rate in the United States is three times as high as it is in Sweden. Id. at 192. Not to be overlooked, however, is the possibility that the difference in rates between Sweden and the United States is due, at least in part, to sociological differences.

16. See note 13 supra.

17. The divorce rate per 1,000 population in Pennsylvania in 1947 was 1.5 and 1.3 in 1948. Nevada had rates of 99.3 and 67.1 for those years. This is of course due to migratory divorce in great part. 31 BUREAU OF THE CENSUS, op. cit. supra note 14.

18. PA. R. Crv. P. 1122 .

19. PA. R. Crv. P. 1124.

20. When the whereabouts of defendant is known, ten days notice of the master's meeting must be given to the attorneys for both parties. Where there is no appearance for the defendant, notice is sent by registered mail and the master has the plaintiff verify the defendant's signature on the return receipt at the meeting. $P A$. $R$. Crv. $P$. $1133(a) *(3)$ (b). (Starred Rules in PA. R. Crv. P. are Philadelphia Common Pleas Court Rules). 
require that the ground or grounds upon which the action is based must be set forth in substantially the statutory language. In practice this results in a statement of the cause of action in precisely the language of the statute. In addition the complaint must contain a prayer for relief and allege that the action is not collusive. ${ }^{21}$ After the complaint has been filed and the case comes to issue it is usually put in the hands of a master.

\section{The Mastership System}

The bulk of the administration of the Pennsylvania divorce law is done by masters. ${ }^{22}$ A master is a member of the bar ${ }^{23}$ who may be appointed by the court on its own motion or after a motion of either party, to hear any case in which there is no petition for a jury trial, or where such petition is denied. ${ }^{24}$ If a case is contested, some judges hear it themselves as a matter of course on the ground that an inexperienced lawyer serving as master in a contested case may be taken advantage of by one or both of the attorneys representing the parties; other judges hear contested cases themselves except when they feel that they can appoint a master who is especially well qualified. Where an uncontested divorce develops into a contest the judge may withdraw the case from the master ${ }^{25}$ unless he feels that the master has special competence. An uncontested case in Philadelphia County, however, is almost invariably heard by a master. Since in Philadelphia, as elsewhere in the nation, the vast majority of divorce actions are uncontested, ${ }^{26}$ the importance of the mastership system is apparent.

Aside from being a member of the bar, a master need not have any special experience or training; each judge selects his masters according to his own standards. ${ }^{2 \pi}$ The masters observed in practice varied from lawyers recently admitted to the bar to older practitioners both with and without much experience in divorce work. A number of attorneys in semi-retirement are occasionally appointed masters. Although a conscious effort to

21. PA. R. Crv. P. 1126.

22. In some jurisdictions the cases are referred to a "referee"; in others the cases are tried in court and there is no delegation to a referee or master. See 2 VERNIER, op. cit. supra note 9, at 137-8.

23. The Philadelphia rules require him to be a member of the bar. PA. R. Crv. P. $1133(\mathrm{a}) *(2)$ (a). Although neither the divorce law nor the rules of court of all of the counties specify that the master be an attorney, the Superior Court has indicated that this is a requirement in all divorce cases. "Although we seem to have no express statutory provision to the effect that a master in a divorce proceeding must be a member of the bar, it is obvious, in view of the duties assigned to him, that one not learned in the law is not competent to act as a master." Langeland v. Langeland, $108 \mathrm{~Pa}$. Super. 375, 377, 164 At1. 816, 817 (1933).

24. Pa. Stat. Ann. tit. 23, \$36 (Purdon Supp. 1952).

25. The court may at any time withdraw a case from a master. PA. R. Crv. P. $1133(\mathrm{a}) *(2)(\mathrm{a})$.

26. KEPBART, op. cit. supra note 4.

27. In some Pennsylvania counties other than Philadelphia, masters are appointed in alphabetical order or according to seniority, or from a board of standing masters, annually appointed. 2 Freedman, Law of Marriage and Drvorce in PenNsylvania 1304 (1944). 
obtain an experienced master is usually made where the divorce is contested, this may not be true in many uncontested cases.

The master's job is to conduct hearings in order to gather the evidence, and to return the record and a transcript of the testimony to the court, together with his report and recommendations. ${ }^{28}$ The Philadelphia rules require that the report contain besides preliminary data such as the times and places of the meetings, a statement as to the service of process, the findings of fact as to the marriage, the cause of the divorce in brief form, the residence and jurisdiction, the age and occupation of the parties, and information as to any children. In addition, the master must summarize evidence on the merits and include such discussion of it as he deems proper. He must set forth findings of fact relating to the ground of divorce established. Finally, there must be included the legal conclusions reached by the master and his recommendation as to whether or not the divorce should be granted. ${ }^{20}$ Ordinarily a master's report does not involve much legal research other than the citation of the leading cases which define the particular ground alleged. Nor do masters discuss what are termed "sociological" aspects of the case, such as the possible effect of the divorce upon the children. Similarly there is no mention of what many feel to be the "real reasons" for seeking the divorce, i.e., financial difficulties or family interference.

In drawing up recommendations in uncontested cases, many masters feel that if the plaintiff has presented a fairly plausible story, there is no tenable basis for disbelieving it, because here the testimony is uncontradicted. Therefore, it is not surprising that the vast majority of masters' recommendations favor granting the divorce. The master's findings of fact and recommendations are only advisory and are not binding on the common pleas court; ${ }^{30}$ it has been repeatedly held that the appointment of a master does not relieve the court of the duty to examine the testimony independently and decide upon the merits of the case. ${ }^{31}$ It is clear, however, that the disposition of the case will depend in large part on the kind of record that has been made at the master's hearing. If the report indicates that the plaintiff has a plausible story and that all the elements required by the statute are present, the master's recommendation that divorce be granted will ordinarily be approved. The tendency of masters to ap-

28. Pa. Stat. Ann. tit. 23, §36 (Purdon Supp. 1952).

29. PA. R. Crv. P. $1133(\mathrm{a}) *(3)(\mathrm{j})$.

30. "This act does not confer on the master the same power as an auditor or a master in equity, nor does it give his findings of fact and recommendations the force and effect of findings of fact by them." Rinoldo v. Rinoldo, $125 \mathrm{~Pa}$. Super. 323, 326, 189 Atl. 566, 567 (1937). "We have repeatedly held that the report of a master is advisory only, and that it is our duty to examine the testimony carefully and make our independent finding. A report of a master who has had the advantage of seeing and hearing the parties and their witnesses, is, nevertheless to be given fullest consideration. . . "Vautier v. Vautier, $138 \mathrm{~Pa}$. Super. 366, 367, 11 A.2d 207, 208 (1940).

31. E.g., Middleton v. Middleton, $187 \mathrm{~Pa}$ 612, 615, 41 At1. 291 (1898) : "It never was intended that the judicial function should in any material degree be relinquished by conducting the proceedings before a master in his office, or that weighty judicial responsibilities should be evaded by shifting it over to a member of the bar." 
prove any claim and judges to approve any record which are prima facie plausible is evidenced by the very high proportion of actions filed which actually result in divorce. ${ }^{32}$

A major purpose of any system for administering divorce laws is to protect the interests of the state in the proceedings. The doctrine is that

". . a divorce proceeding is quite different from an ordinary civil action, as it has its own distinguishing features to be considered.

"While an action to dissolve a marital relationship is nominally between two parties, the state, because of its concern in maintaining the marriage relation, unless good cause is shown for its dissolution, is an interested party. It has been recognized by eminent writers on the subject, as well as . . . decisions, that it is really a triangular proceeding, in which the husband, the wife and the state are involved. While the state does not necessarily oppose, it is the duty of a court to see that when an attempt is made to sever the relation it shall not prevail without sufficient and lawful cause shown by the real facts on which the state permits a divorce to be granted, and to discover and defeat any attempted collusion and fraud. There is a liberal legal discretion vested in the courts to accomplish this purpose." ${ }^{33}$

This need to protect the concerns of society is especially pressing in uncontested cases, where there is no adversary present to serve as a check on the plaintiff. The theory behind the mastership system is that the master through his hearing can, without consuming the time of the courts, serve both the function of a finder of facts and the quasi-judicial function of an impartial referee. ${ }^{34}$ To perform the first of these duties the master must not merely determine whether the plaintiff and his attorney have prepared and presented a case which satisfies the statute, but he must use all the

32.

$\begin{array}{cccc}\text { Year } & \begin{array}{c}\text { Number of } \\ \text { Divorces Filed }\end{array} & \begin{array}{c}\text { Number } \\ \text { Granted }\end{array} & \begin{array}{c}\text { Percent } \\ \text { Granted }\end{array} \\ 1938 & 2012 & 1713 & 85.14 \\ 1946 & 6590 & 5273 & 80.01 \\ 1947 & 4829 & 4576 & 94.76 \\ 1948 & 4255 & 3866 & 90.85 \\ 1949 & 3821 & 3380 & 88.47 \\ 1950 & 4198 & 3167 & 75.44 \\ 1951 & 4040 & 3266 & 80.84 \\ 1952 * & 2443 & 1859 & 76.09\end{array}$

The figures were supplied from unofficial records kept in the office of the Prothonotary in Philadelphia. Since many of the divorce actions filed are dropped before any judicial decision is reached, the difference between the number of cases filed and the number of divorces granted does not represent the number of cases in which a divorce was denied by the court. Thus, the proportion of cases decided which result in a grant of divorce is even higher than the percentages indicate.

33. Hall v. Hall, 122 Pa. Super. 242, 246, 186 Atl. 318, 320 (1936).

34. "A master occupies, for the time being, a quasi judicial position, which requires as strict impartiality on his part as if he were a judge hearing the case." Kolopen $v$. Kolopen, 148 Pa. Super. 311, 313, 25 A.2d 569, 570 (1942). 
means at his disposal to ascertain the true situation. The quasi-judicial status of a master requires that he interpret his duty not as one of helping to make out a case for the libellant, but as a duty of strict, judge-like impartiality.

\section{The Master in Action}

Preliminaries.-One of the facts which the master is to ascertain is the correctness of the residences of the parties if given as being within Philadelphia County. ${ }^{35}$ There appears to be general compliance with this requirement. $^{38}$ Many masters make it a practice to call personally at the addresses given; others will call the telephone number listed at the address given and ask for the party, or utilize a registered letter with a return receipt requested. In Philadelphia the rules require that the plaintiff deposit $\$ 125$ with the Prothonotary when a master is appointed. ${ }^{37} \$ 100$ is for the compensation of the master and $\$ 25$ for the official court stenographer, who is required to record the testimony at the hearing. ${ }^{38}$ Ordinarily the $\$ 100$ will cover one meeting and perhaps two; however, if the second meeting is at all extensive or if further meetings are required the master will usually request additional compensation, which is generally granted by the court.

The Hearing.-After ten days' written notice to the attorneys for both parties, ${ }^{38}$ the master holds a hearing. Some courts make court rooms or other places in City Hall ${ }^{40}$ available for the meetings. It is considered desirable to hold the proceedings at City Hall not only because of the convenience to the court stenographer and the parties, but also because of the added formality and solemnity of the surroundings. However, masters may hold the meetings at their own offices if they desire, and this is often the case. The master, stenographer, plaintiff, plaintiff's attorney, and any witnesses who have been summoned are usually the only persons present, in accordance with the confidential nature of divorce actions.

At the outset of the meeting the master swears in the plaintiff. Some masters make an obvious effort to impress the plaintiff with the importance of the oath, while with others the act is perfunctory. After the oath is administered the marriage is established. This will ordinarily entail testimony as to the date and place of marriage and the person who performed the ceremony, at which point the plaintiff's attorney introduces into evi-

35. PA. R. Crv. P. 1133(a)*(3) (e).

36. See text at note 41 infra.

37. PA. R. Crv. P. 1133(a)*(2) (b). The case will not proceed if the required sum is not deposited. Note that this fee is in addition to counsel fees and thus may cast an onerous burden on those of low income who seek divorce.

38. Ibid.

39. PA. R. Crv. P. 1133 (a)*(3) (b).

40. In Philadelphia, City Hall is the seat of both the city and the county governments. The equivalent in most Pennsylvania counties would be the county court house. 
dence the certificate of marriage which becomes part of the record of the case. After the marriage is established the residence and judisdictional facts are ascertained. The Philadelphia Rules of Court require that the master report the residences of the parties at the time they were married, each place they have resided since, and the exact number of years and months each has resided in Pennsylvania.41 Caution, jurisdiction-wise, is commendable, but sometimes this procedure involves rather extended examination where the residences have been many and the dates remote. Nevertheless, masters are generally anxious to prevent any discrepancies which might be apparent on a review of the record.

Other routine facts which the master must establish are the ages and occupations of the parties; their race (for statistical purposes); whether either is in the armed forces; ${ }^{42}$ whether either has been previously married (a prior divorce must be proved by means of a final decree); the date of the last act of intercourse between the parties; ${ }^{43}$ and who is paying for the divorce. It must be ascertained whether there are any children and if so, their names, ages, residences, and with whom they are living. ${ }^{44}$ In practice the names and ages of any children are put on record and beyond this the subject of children ordinarily is not dealt with except where the children are involved in conduct alleged as grounds for the divorce, or where the plaintiff wishes to show that he has been a dutiful parent. At some point in the proceedings prior to the narrative of the facts alleged as grounds for divorce, the master verifies the plaintiff's signature on the complaint. This is done by displaying the complaint to the plaintiff and asking him or her whether it is his or her signature that appears thereon. The absence of collusion must also be proved. This is almost always done by means of a single question such as the following:

"Q. Has there been any agreement between you and him not to contest this divorce?

"A. No."

Occasionally the master will ask a further question such as :

"Q. Is the action in divorce being brought in all seriousness and good faith?

"A. Yes."

Such questions seem more designed to comply with technical requirements than to elicit any real information.

41. PA. R. Civ. P. $1133(\mathrm{a}) *(3)(\mathrm{j})$.

42. The Soldiers' and Sailors' Civil Relief Act provides special protection for a defendant who is in the armed forces. PA. R. Crv. P. $* 921$.

43. ". . . it is well established that when the alleged deserting wife comes to her husband and has marital intercourse with him, that breaks the continuity of the desertion." Trussell v. Trussell, $116 \mathrm{~Pa}$. Super. 592, 601, 177 At1. 215, 219 (1935). 44. PA. R. Crv. P. $1133^{*}(3)(j)$. 
Many masters have with them at the meeting a check list which contains all the essential questions, i.e., those which may be omitted only at the risk of recommittal of the case to the master for the procuring of additional testimony. ${ }^{45}$ Recommittal is most undesirable for the master, for aside from the time, trouble and embarrassment involved, it may cause the judge to hesitate before giving another master's appointment to that attorney. If no check list is at hand the master may turn to the official court stenographer for prompting, especially where the master has had little experience in divorce cases. Because of personal curiosity or because it is believed an aid in the decision, masters sometimes seek background information other than that considered essential, such as the parties' religion or any history of arrests. With so much information collateral to the main issue to be gleaned, and with the emphasis which masters often place on details like jurisdictional requirements, it often results that as much time and effort is devoted to the development of background information as to the merits of the case. It is obvious that routine matters must consume a substantial portion of the typical meetings which last from 45 to 60 minutes.

The Merits.-When the master is satisfied that he has secured all the necessary preliminary information he will go on to the substantive part of the case. This is elicited primarily from the plaintiff. The Philadelphia Rules of Court require that the master examine each witness in detail upon all averments of the complaint, ${ }^{46}$ and that neither party shall be allowed to examine any witness until the master has finished his examination. ${ }^{\text {t? }}$ Actually many masters do not comply fully with the spirit of this rule in that they merely recite the grounds alleged in the statutory language and ask for the story in general terms. It seems somewhat unrealistic to expect effective, searching inquiry from one completely unfamiliar with the case, as is the master at the outset of the meeting. Frequently the master turns the plaintiff over to plaintiff's lawyer to develop the facts of the case. Where the master intends to attempt the development himself he will begin in this way:

"Q. You allege in your complaint in divorce that on January 10, 1946, at _____ Street, Philadelphia, Pa., your husband willfully and maliciously and without reasonable cause deserted you, the injured and innocent spouse, and has persisted in said desertion from the said date, thence hitherto.

"Will you tell me in your own words the troubles you had in your married life and the events leading up to this alleged desertion?"

In addition to the interrogation of the plaintiff there may be testimony of corroborating witnesses. The master has a duty to call as a witness

45. It has been suggested that a face-sheet type of questionnaire might be used here to better advantage. This would save time, make for more complete coverage, and provide statistics more readily. KEPHART, op. cit. supra note 4.

46. PA. R. CIv. P. $1133(\mathrm{a}) *(3)$ (f) (2).

47. PA. R. CIv. P. 1133 (a)*(3) (f) (3). 
anyone whom he has reason to believe has knowledge of relevant facts, whether or not requested to do so by either party. ${ }^{48}$ In practice little effect is given to this rule, since most cases are disposed of in one hearing and the master has no knowledge of the case prior to this meeting. Any corroborating witnesses who are present are generally brought by plaintiff's attorney in recognition of the customary requirements of the particular judge who is to review the testimony. Typical testimony of a corroborating witness is described below. ${ }^{49}$

Particularly in interrogation of the plaintiff and other witnesses on the merits of the case is it essential for the master to perform his dual functions of impartial judge ${ }^{50}$ and perceptive examiner. ${ }^{51}$ In most respects the ordinary rules of trial procedure apply, with the master empowered to rule on any objections to the competency or relevancy of testimony. ${ }^{52}$ Of course, in the typical uncontested case, since there is no adversary to object, the responsibility for the exclusion of hearsay and leading questions is the master's. Yet, although many cases have been recommitted to the master because of the use of leading questions by the master or one of the attorneys, ${ }^{53}$ many masters permit such examination by attorneys. The masters themselves almost universally use leading questions to some extent; some use them almost exclusively. As one master put it, "[s] ome of the plaintiffs don't know how to get their story out, and we've got to help them." While this is undoubtedly true in many cases there is obvious danger of abuse by one who is relatively inexperienced in the judicial function; at any rate the use of leading questions alone is not always the method of examination most conducive to penetrating discovery of the facts.

\section{LaW and Practice}

The masters' interrogation on the merits of the case should be designed to reveal whether or not the substantive requirements as to grounds for divorce have been met. Yet, comparison of the grounds most commonly used in Pennsylvania as formulated by statute and appellate interpretation with typical handling by masters, illustrates the extent to which administration differs from legal doctrine.

Desertion.-Ground for divorce is established when it shall be judged "that the other spouse ... [s] hall have committed wilful and malicious

48. PA. R. CIv. P. 1133(a)*(3) (f) (2).

49. See text after note 67 infra.

50. See text at note 34 supra.

51. See text at note 33 supra.

52. PA. R. Crv. P. $1133(\mathrm{a}) *(3)(\mathrm{f})(4)$. It has been pointed out that some departures from normal trial procedure are inherent in the special character of the divorce proceeding. 2 FreEdMan, LAW OF MARRIAGE AND DIvorce IN PENNSYLVANIA 1317 (1944).

53. E.g., Burns v. Burns, 6 Pa. D. \& C. 437 (1924); McCracken v. McCracken, 72 Pitts. L.J. 268 (1923). The court refused to consider evidence elicited by leading questions in Kolopen v. Kolopen, 148 Pa. Super. 311, 25 A.2d 569 (1942). 
desertion, and absence from the habitation of the injured and innocent spouse, without a reasonable cause, for and during the term and space of two years." 54 The willful and malicious character of the desertion is established by a mere finding that the desertion was intentional, for it has been held that "if the desertion is intentional it is willful; if willful it is malicious." 55 It must be further established that the willful and malicious character of the desertion persisted for the entire two year period. ${ }^{56}$ There must be an actual physical absence from the habitation ${ }^{67}$ and it must be shown that the abandonment of marital cohabitation was without consent ${ }^{58}$ or good cause. ${ }^{5 \theta}$ The mere failure by a husband to support the family properly does not constitute desertion and is not in itself a ground for divorce. ${ }^{60}$ The deserted spouse has no legal duty to seek a reconciliation or return of the deserting spouse-that is, the failure to attempt to effect a reconciliation will not be fatal to a divorce action. ${ }^{61}$ However, if the deserting spouse makes a bona fide offer to resume cohabitation, the desertion will be held to have terminated; ${ }^{62}$ furthermore, if such an offer is not accepted, the originally deserted spouse will be held to be a deserting spouse. $^{.3}$ It should be emphasized that a mere showing of a departure is not sufficient to prove desertion; surrounding circumstances must be shown which are indicative of the requisite intent. ${ }^{84}$

The development of a desertion case in practice is illustrated by the following testimony taken in a typical case. On being asked to tell the story of the marriage and its difficulties the plaintiff answered:

"Well, we just simply had an argument and he just got up and walked out, and he didn't return for two days. . . .

"Q. And you didn't see him for two days?

"A. No I did not. He went to his mother's home, and I called and asked him if he was there, and they said yes. So I asked him if he was coming back, and he said that he wasn't ready. Naturally, I was worried about whether he was returning home or not. So he returned two days later and got his clothing.

"Q. When did your troubles with him first begin?

"A. Oh, when he was still in the service. ..."

54. Pa. Stat. Ann. tit. 23, $\$ 10$ (Purdon Supp. 1952).

55. Partleton v. Partleton, 169 Pa. Super. 485, 488, 82 A.2d 684, 685-6 (1951).

56. Ingersoll v. Ingersoll, $49 \mathrm{~Pa} .249$ (1865).

57. Wacker v. Wacker, 55 Pa. Super. 380 (1913).

58. Bracken v. Bracken, $77 \mathrm{~Pa}$. Super. 219 (1921).

59. Dash v. Dash, $357 \mathrm{~Pa}$. 125, 53 A.2d 89 (1947) (A woman who has good grounds for believing that her husband is unfaithful to her, may leave his home without being guilty of desertion).

60. Ingersoll v. Ingersoll, $49 \mathrm{~Pa} .249$ (1865). The wife's remedy here is a support order. Gumbert v. Gumbert, 47 Pitts. L.J. (O.S.) 110 (1899).

61. Winner v. Winner, 122 Pa. Super. 382, 186 At1. 245 (1936).

62. Noden v. Noden, 111 Pa. Super. 513, 170 Atl. 465 (1934); Hort v. Hort,

$111 \mathrm{~Pa}$. Super. 119, 169 Att. 401 (1933).

63. Barnes v. Barnes, 21 Pa. D. \& C. 101, 104 (1934).

64. Price v. Price, $83 \mathrm{~Pa}$. Super. 446 (1924). 
The testimony then becomes an account of all the inpleasant experiences that the plaintiff can remember of her married life. There is usually only perfunctory inquiry into the conduct of the plaintiff during the marriage which might have furnished provocation for the acts of the defendant. The master will often, however, inquire into the size and character of the living quarters in which the parties resided. The theory seems to be that if the living quarters are adequate it might negative justification for the defendant's leaving the home. Very often if the plaintiff is the wife she will be examined as to the efforts made by the defendant to support the family during the marriage. For example, the master may ask:

"Q. Did he make any attempt to secure any work from October, 1945, to January, 1946?

"A. No, he did not. His mother told him he wasn't well enough to work."

A willful refusal by the allegedly deserting husband to support the wife is some evidence of the intent to desert. However, it has been held that non-support in itself does not constitute desertion, nor is a mere showing of departure from the home sufficient to prove desertion. ${ }^{\text {sa }}$ In order to show the departing spouse's intention to desert there is usually testimony that the defendant took his or her clothing along, and that defendant rejected the plaintiff's request to return. Some typical testimony follows:

"Q. Did you have a conversation with him at that time?

"A. Yes, I did.

"Q. What was the conversation about?

“A. I asked him to come back, and he said no, he just couldn't stand me. . . ."

It has been seen that an offer by the defendant to return terminates the desertion. ${ }^{60}$ An experienced master may cover this point in the following manner:

"Q. Did he on any occasion ever offer you a home?

"A. He did not.

"Q. Did he ever offer to return to the former place of residence?

"A. No, he did not."

The surrounding circumstances are relevant in a desertion case to show intent to desert, and also to show that the plaintiff is an injured spouse who has not provided any justification for the defendant's act. Invariably the defendant is made out to be completely in the wrong.

"Q. When you lived with your husband were you always a dutiful wife?

"A. Yes, I was.

65. Smith v. Smith, $85 \mathrm{~Pa}$. Super. 74 (1925).

66. See text at note 62 supra. 

husband?

"Q. Did you always provide for the means and care of your

"A. Yes. child?

"Q. Did you always properly take care of his child and your

"A. Definitely.

"Q. Did you give your husband any reason for justification or excuse for leaving you?

"A. No.

"Q. Was it a question of money with you?

“A. No, I don't think it was; I'd say no it wasn't. . . . "Excused."

One can only conjecture as to how the story would sound if told by the husband in this case.

It is common knowledge among members of the bar in Philadelphia who handle divorce cases that certain of the common pleas courts prefer or require corroboration in divorce cases where the ground alleged is desertion. To be safe, the plaintiff's lawyer brings in a friend or a relative to testify. Many masters make no attempt to question the witnesses called by the plaintiff. They merely ascertain the name and address of the witness and turn the examination over to the plaintiff's lawyer on the theory that this procedure will save time, since they do not know the purpose of the plaintiff's lawyer in calling the witness. The advantage of this method was demonstrated in some of the meetings observed, where the master attempted the initial examination and found that the witness professed to have no knowledge of the matters inquired about. Initial examination by the plaintiff's attorney seems to contravene the rule of court which requires that: "Neither party shall be allowed to examine any witness until after the master has finished his examination. . . ." 67 A typical corroborating witness may testify as follows:

"Q. Do you know whether they separated?

"A. Yes. . . .

"Q. Do you know the reason for the separation?

"A. It was over an argument, and he left. . . .

"Q. Since January 10, 1946, do you know whether or not George

B. has stayed any night at your mother's home?

"A. No, he hasn't.

"Q. Will you please tell the master how your sister treated her husband?

"A. She treated him very good.

"Q. What sort of housekeeper is she?

"A. Very good.

67. PA. R. CIV. P. 1133 (a)*(3) (f) (3). 
[Vol. 101

"Q. Does she take proper care of her child?

"A. Yes, she does.

"Q. At the time they lived together did she take proper care of her husband?

"A. Yes, she did.

"Q. Did she provide for his wants and comfort?

"A. Yes.

"Q. Do you know of any reason or excuse or justification that George $B$. might have had for leaving his wife?

"A. No, I don't.

"Excused."

Cruel and Barbarous Treatment and Indignities.-_". . . [I]t shall be lawful for the innocent and injured spouse to obtain a divorce . . . whenever it shall be judged, in the manner hereinafter provided, that the other spouse ... [s] hall have, by cruel and barbarous treatment, endangered the life of the injured and innocent spouse." 68 Actual personal violence or the reasonable apprehension of such violence is required to establish cruelty. ${ }^{69}$ While a single act, if sufficiently severe, may constitute cruelty, ${ }^{70}$ it must be such that the life of the innocent spouse is endangered. Some of the acts which have been held not to support a divorce on the cruelty ground are humiliating charges, ${ }^{71}$ refusal of sexual intercourse, ${ }^{72}$ indifference and neglect. ${ }^{73}$ However, much of the conduct which does not constitute cruelty is serious enough to meet the statutory standard for the indignities ground. To insure successful action many lawyers allege both cruelty and indignities or desertion in their complaint. Then, when the master's meeting stage of the proceedings is reached, the plaintiff's lawyer is apt to declare that the cruel and barbarous ground is not being pressed and he will proceed on the other ground alleged. It is felt that it is easier to make out a case on the grounds of indignities or desertion. ${ }^{74}$

For indignities the statute requires that the defendant "[s] hall have offered such indignities to the person of the injured and innocent spouse, as to render his or her condition intolerable and life burdensome." ${ }^{75}$ The statute is vague in that it provides no definition of what constitutes an indignity. Vulgarity, unmerited reproach, habitual contumely, studied neglect, intentional incivility, manifest disdain, abusive language, malignant ridicule and every manifestation of settled hate and estrangement are some of the common judicial formulations of the acts sufficient to constitute

68. Pa. Stat. Ann. tit. 23, $\$ 10$ (Purdon Supp. 1952).

69. See Apelian v. Apelian, 111 Pa. Super. 208, 169 Atl. 454 (1933).

70. May v. May, $62 \mathrm{~Pa} .206,210$ (1869).

71. Melvin v. Melvin, 130 Pa. 6, 18 Atl. 920 (1889).

72. McCommons v. McCommons, $85 \mathrm{~Pa}$. Super. 323, 328 (1925).

73. Ingram v. Ingram, $58 \mathrm{~Pa}$. Super. 522 (1914).

74. See note 9 supra.

75. PA. Stat. Anv. tit. 23, § 10 (Purdon Supp. 1952). 
indignities to the person. ${ }^{78}$ Unlike cruel and barbarous treatment, indignities cannot be established by a single act, no matter how severe. The evidence must disclose a course of conduct which indicates continued mistreatment. Causes which are not recognized as rising to the statutory standard for indignities are: incompatibility, ${ }^{77}$ lack of affection, ${ }^{78}$ habitual drunkenness per se ${ }^{79}$ and poor performance of household duties. ${ }^{80}$ In addition, as is the case with other grounds for divorce, if the conduct complained of takes place during a time when the defendant was insane ${ }^{81}$ or is caused by ill health, ${ }^{82}$ no divorce may be granted. This is because the requisite intent is negatived. Since the statute requires that the condition of the innocent spouse be rendered intolerable and his life burdensome, a great deal depends on the sensibilities of the individual plaintiff. Manifestly, a very sensitive person may find unbearable conduct which another might consider quite normal. ${ }^{83}$

Where the grounds alleged are indignities the master has even less guidance from the complaint in his examination of the plaintiff than in a desertion case, where he at least knows that the plaintiff must prove a departure and an absence of two years. Also, since the definition of indignities is at best rather vague and uncertain, ordinarily the master will simply have the plaintiff tell the story of the marriage with emphasis on all the ill treatment and abuse inflicted by the defendant. An illustration from a case follows:

"Master: You charge the defendant with indignities to the person commencing in September, 1947, and continuing until June 12, 1951. Will you start from the beginning and in your own words relate for the record, the circumstances?

"A. The time we were married, when I moved to Newport, why, everything went all right for a while, and then she started going out, came in all late hours under the influence of drink, and any time I had any few friends up, like $\mathrm{Mr}$. or Mr. and his wife, why, she would tell me how much she hated me and use all kinds of foul language and it kept continuing. . . .

"Q. Would you give us an example of the kind of language she used toward you?

76. Konosa v. Konosa, 165 Pa. Super. 140, 143, 67 A.2d 662, 664 (1949).

77. Ingram v. Ingram, $58 \mathrm{~Pa}$. Super. 522 (1914).

78. Breed v. Breed, $73 \mathrm{~Pa}$. Super. 9 (1919).

79. Mason v. Mason, $131 \mathrm{~Pa} .161,164,18$ At1. 1021 (1890).

80. Schulze v. Schulze, $33 \mathrm{~Pa}$. Super. 325, 327 (1907).

81. Tait v. Tait, 12 Pa. D. \& C. 25 (1929).

82. Crock v. Crock, $96 \mathrm{~Pa}$. Super. 377, 383 (1929), "The conduct of which libellant complains seems to have resulted largely from her highly nervous condition which, as he was well aware, was caused by her physical condition. The law does not recognize conduct resulting from such causes as a ground for divorce."

83. Although ordinary sensibilities are usually said to be the standard, courts do make allowances for the plaintiff's sensitivity or lack of it. See Shilko v. Shilko, 131 Pa. Super. 395, 397, 200 At1. 127, 128 (1938). 
“A. You __ I don't like you and never did. I don't know why I married you in the first place. . . .

"Q. Did she keep house for you very well?

"A. No, the house always looked like a pig pen. I had to do all of the house work myself to keep the place clean. . . . And then finally she introduced me to this guy and she said he was in love with her. . . .

"Q. You tried to persuade her to change her mind?

"A. Oh, numerous times, it did no good.

"Q. Did she ever call you names or abuse you in front of your friends?

"A. Yes, many times.

"Q. And she would curse you at these times?

"A. She would curse me, rave and take off, start arguments, try to fight with me.

"Q. As far as you know was there any reasonable cause for these arguments?

"A. As far as I know, no. I tried to do my best.

"Q. Did you do anything to prevent the incidents? . .

“A. No, I didn't. duct?

"Q. What reason would you assign, if any, for your wife's con-

"A. As far as I could see, she was just out after the allotment she was getting from me. When she was first married she said she didn't love me or anything, all she wanted was what she was getting out of me, she was getting her support from me.

"Q. Mr. ___ do you have any letters or statements from the defendant to substantiate your claims?

"A. No.

"Q. Is there anything else you would like to state in support of your case?

"A. No.

"Q. How frequently, how many times a week would you say that she called you these names that you refer to?

"A. Once or twice a week at least.

" $Q$. Was that a continuous course during the period commencing with September, 1947, and going to the date of your separation in June, 1951?

"A. Yes, sir.

"Q. Except the time that you were overseas?

"A. Except the time I was away."

Corroborating witnesses are frequently introduced in indignities cases, but this depends a great deal on the judgment of the plaintiff's lawyer as to the attitude of the reviewing court. In the case from which the above 
extract was taken, the plaintiff who was in the Navy, called a shipmate to testify. It should be noted that the witness will ordinarily testify after having heard the plaintiff's testimony. The shipmate testified as follows:

"Q. How frequently would you say you went to their home?

"A. Oh, at least once a week, sir.

"Q. What did you observe with regard, first, to the manner in which the home was being kept? Was it a tidy home?

"A. I wouldn't call it well kept. It looked like a man was taking care of the place.

"Q. What, if anything, did you observe with regard to the behavior of the defendant in regard to the plaintiff.

"A. I say it was generally abusive.

"Q. Would you be a little more specific and tell us what you heard and what you saw on your visit to this home?

"A. All I know, Mr. 's wife used extremely foul language at times. It seemed every time we went over and played cards she would start picking on him.

"Q. What, if anything, did she say to him in your presence?

"A. Well she called him nasty names.

"Q. Such as what?

"A. She called him a several times and called him a that I know of.

"Q. In your presence?

"A. In the presence of my wife and myself. . . .

"Q. Did you observe the course of conduct, whether or not the course of conduct by the defendant had any effect on $\mathrm{Mr}$.

"A. Yes, it hurt the man.

"Q. Did he appear to be nervous?

"A. Nervous and angry, and generally shook up you might say, irritable. . . .

"Q. Have you noticed any change in the condition of his health since then?

"A. Well, he is considerably more cheerful, more like his normal self.

"Lawyer: That is our case, Mr. Master."

As indicated above, neglect of household duties, bad temper, occasional quarrels are not in themselves sufficient to constitute indignities. It has been held, however, that such evidence may be considered in the general scrutiny of the defendant's conduct. ${ }^{84}$ While testimony in the form of general accusations and conclusions has repeatedly been held to have no evidentiary value, ${ }^{85}$ plaintiffs continue to utilize these generalities.

84. Cutter v. Cutter, $165 \mathrm{~Pa}$. Super. 103, 68 A.2d 192 (1949).

85. E.g., "The acts of the parties are to determine the merits of the controversy. General accusations of a bad temper, of a nagging disposition and of disagreeable conduct towards relatives of the libellant, are not sufficient. A complainant who 
Actually, much of the testimony presented to establish a ground for divorce is largely intended to show that the defendant was generally a disagreeable person and a poor spouse. This is true in both desertion and indignities cases. For example, mere claims by the plaintiff of nervousness and adverse effects on his health are supposedly valueless, ${ }^{86}$ yet this type of evidence is almost universally utilized. It is difficult to determine just how much effect this kind of evidence has, but interviews with masters immediately after they had heard the testimony indicate that many masters come away from the meeting with the general impression that the defendant is a completely unworthy person. This may be very important to the decision in the case, depending upon the attitude of the particular master toward the divorce law.

\section{Evaluation}

The story of divorce administration in Philadelphia is essentially the story of the mastership system. The extent to which masters comply with and enforce the statute is more significant than appellate court decisions ${ }^{\mathrm{st}}$ in terms of the actual conditions under which the vast majority of divorces are granted. If the testimony in divorce cases is to be effectively scrutinized at all, the master's hearing would seem to be the place to do it, since the master has the opportunity to see and hear the witnesses and observe their demeanor. In fact, the master has not only the means, but the affirmative duty to scrutinize the testimony offered. If the state has an interest in preventing indiscriminate divorces, it is up to the master to protect that interest in the typical uncontested case where there is no adversary serving as a check on the plaintiff.

It is apparent that many masters seriously misapprehend their statutory function. Many lawyers conceive the function of the master to be merely to decide whether a case has been made out; even judges are sometimes inclined to consider it sufficient that the interests of both parties have been

seeks to secure a divorce on such a charge . . . must establish a course of conduct by evidence of specific importance and quality to make out a case. Inferences, loose declarations, general allegations of ill-temper and abusive conduct fall short of this obligation." Abbott v. Abbott, $75 \mathrm{~Pa}$. Super. 483, 504 (1921).

86. Rose v. Rose, $124 \mathrm{~Pa}$. Super. 437, 188 Atl. 595 (1936).

87.

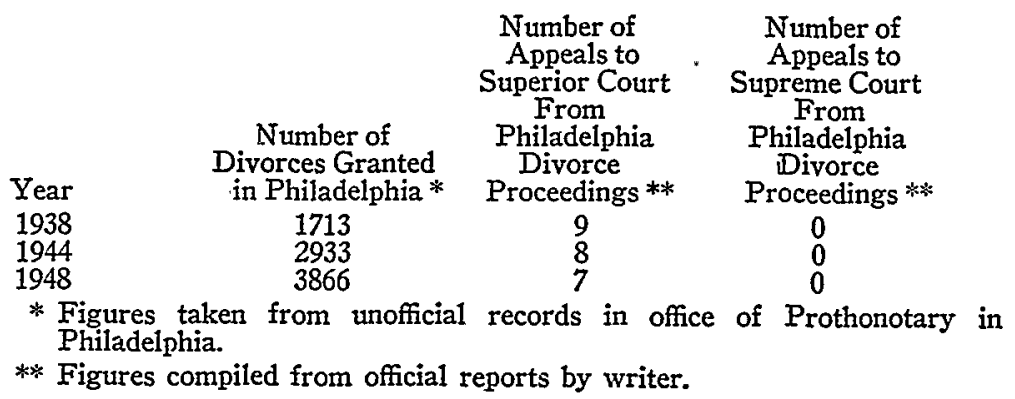


protected, overlooking the state's interest in the matter. ${ }^{88}$ Some lawyers even feel that the master should aid the plaintiff in the presentation of his case and the occasional master who diligently probes the plaintiff's allegations is likely to find himself the object of other lawyers' criticism for treating the plaintiff "like a defendant in a criminal trial."

Many aspects of the mastership procedure as outlined above raise serious doubts as to the effectiveness of the search for facts conducted by most masters today. Typically, the substantive facts come chiefly from the plaintiff, who may be led by his attorney or by the master if he is slow or ineffective in making a case. If there are corroborating witnesses they are generally supplied by the plaintiff and will first hear the plaintiff's story before being called to bolster it. The master's questioning tends to be perfunctory, with the master eyeing technical requirements or a particular judge's demands rather than attempting to make the most of his first hand opportunity to learn all the facts of the case. Rarely does a master exercise his power to call a witness on his own motion. A misplaced emphasis on jurisdictional requirements is often present. The purpose of jurisdictional requirements is to prevent migratory divorce, but statistics indicate that migratory divorce is a problem in only a small percentage of cases. $^{89}$ Perjury and collusion are at least suspected in a majority of cases, ${ }^{90}$ yet the kind of searching inquiry which might disclose perjury or collusion is seldom resorted to. All too often general charges and accusations play an important part in the testimony.

In addition to representing the state as investigator, the master is expected to be an impartial judge. That it may sometimes be unrealistic to expect an absolutely impartial judicial performance is illustrated by an episode related by one of the official court stenographers. Two master's meetings were scheduled in a single day. After the first one was over the plaintiff's lawyer and the master had lunch, came back, changed places at the table, and the master in the prior case became counsel for a different plaintiff. The plaintiff's lawyer in the prior case happened to have been appointed master in the second case. While this may not happen very often, the master, if he does any amount of divorce work at all, knows that he is likely to appear before the plaintiff's lawyer who may be appointed master in a subsequent case.

Another factor in the decisions which may not be apparent in the review of the record is the attitude of the masters toward the divorce law. Many feel that the statute is either too stringent or too lax and as a result

88. See text at note 33 supra. In a letter to the UnIversity of Pennsylvania LAw ReviEw dated August 5, 1952, one Philadelphia judge expressed satisfaction with the present mastership system, stating, "The rights of the litigants are protected by the Court's examination of the evidence and the exceptions taken thereto. . . " No mention was made of any interest other than that of the litigants.

89. Although based on admittedly inadequate and outmoded evidence, the sociology texts usually give $3 \%$ as the frequency of migratory divorce. GrovEs, THE CoNTEMTPORARY AMERICAN FAMILY (1947).

90. Cuber, Sociology, A Synopsis of Principles 402 (1947). 
either unconsciously or consciously tend to conduct and decide the case in accordance with their own ideas. Much of the difficulty in the administration of the divorce law seems to stem from the fact that in all cases an adversary procedure is prescribed, whereas in the overwhelming majority of cases there is actually no adversary interest present. One authority described the situation thus:

". . . although in some 90 per cent of cases the defendant stays carefully away, the plaintiff must, nevertheless, put on an exhibition of shadow-boxing and give the shadow a knockout to the satisfaction of the law. Whoever originated the forms and procedures for divorce litigation little realized that he was setting the stage for a sham battle against the little man who isn't there. Yet to this day all our forms and procedures remain those designed for adversary litigation." 91

\section{Alternatives}

An obvious alternative to the mastership system, and one utilized in some Pennsylvania counties, is to have the judges themselves hear all divorce cases, contested and uncontested. The reason generally given for using masters rather than this procedure is that masters save the courts' time, since the courts are too busy with other work to hear all divorces. ${ }^{92}$ It may be questioned just how much of the judges' time is actually saved in view of the fact that in the typical case there is just one master's meeting which lasts from 45 to 60 minutes; although the judge is relieved of these hearings, he still has the duty to read and evaluate the testimony.

One modification of the present system might be to make the masters permanently appointed specialists, who would become expert in this type of litigation. Any system for hearings can be supplemented by a procedure for the detection of perjury, fraud, and collusion. In England the public interest is protected by an officer known as the Proctor, who intervenes, instructs counsel when so directed by the court and investigates the possible existence of collusion. ${ }^{93}$ In the United States less than half the jurisdictions have any provision for an office which resembles the Proctor, and those statutory provisions which do exist generally cut down the scope of the office.

One fault with present divorce procedure is the absence of any provision for an attempt to heal the marital rift. This need has been recognized by recent proposals for reforming divorce procedure. Expressing the conviction that our present divorce laws "are themselves a continuing threat to the stability of marriage in contemporary America," the American

91. Alexander, The Follies of Divorce: $A$ Therapeutic Approach to the Problem, 36 A.B.A.J. 105, 107-8 (1950).

92. It has been suggested that an additional reason for the mastership system is to give lawyers an opportunity to make a fee. Letter by a Philadelphia judge to the University of Pennsylvania Law Review, August 5, 1952.

93. 2 Vernier, American Family Laws 93 (1932). 
Bar Association Delegation to the National Conference on Family Life in May, 1948 recommended the establishment of family courts. These courts would be presided over by judges who specialize in the field, aided by staffs which include psychiatrists, investigators and social case workers. ${ }^{94}$ In Pennsylvania, a committee of the bar association has been investigating the desirability of a revision of the divorce procedure. This committee has found that there is general agreement that conciliation by trained people is necessary; ${ }^{95}$ such conciliation should be attempted as soon as possible after domestic discord is detected.96

Whatever changes might be attempted in current divorce legislation or administration, a vital consideration is that the law as it exists in theory and as it is practiced should be brought more in line with each other. The interest of the legal profession requires a genuine concern for the enforcement of the law that prevails in the jurisdiction; an unenforced or unenforceable statute breeds disrespect for law in general. Whether recent criticisms of the divorce law are wholly justified or not, lawyers should be the first to concern themselves with the problem. Whether practice is to be made to conform with the law or the law with practice, a reappraisal of the procedure for divorce is in order.

94. Report of the Delegation of the American Bar Association to the National Conference on Family Life, 73 ANN. REP. A.B.A. 302 (1948). An attempt to establish a family court in Philadelphia has been held unconstitutional. Margiotti v. Sutton, 327 Pa. 337, 193 Atl. 250 (1937).

95. Report of the Special Committee on Marriage and Divorce Laws and Fanily Courts, 57 Ann. ReP. PA. B.A. 143, 145 (1951).

96. It has been suggested that once the complaint is filed it is too late for reconciliation, and that therefore it would be best to require a declaration of intent to file a complaint in divorce; at the filing of such a declaration conciliation service slould be available. Miner, Conciliation Rather Than Reconciliation, 43 ILI. L. Rev. 464 (1948). 